\title{
MANAJEMEN PASAR TRADISIONAL BERBASIS WEB DI KABUPATEN JEMBRANA
}

\author{
I Gusti Putu Suwiarta Aquariawan'1 \\ Universitas Triatma Mulya, Jembrana ${ }^{1}$ \\ email: suwiarta.aquariawan@triatmamulya.ac.id
}

\begin{abstract}
Traditional markets play a very important role in the economic activities of the community, especially for sellers of products of basic necessities produced by small and medium-sized and micro economic actors. The development of information technology as we know it is growing rapidly. It would be very beneficial if the Jembrana district government could take advantage of the current information technology to support the data and information needs of traditional markets in the Jembrana district. This study provides a solution for data processing and information on traditional markets in Jembrana district, namely the traditional web-based market management. With this system, it is hoped that Market Managers in Jembrana Regency can manage and manage the market more professionally with the help of information technology. In addition, this system also serves as information about traditional markets to the public consisting of market location map information, the latest information on market PDs, as well as information on price updates of goods from each market PD in all Jembrana district.
\end{abstract}

Keywords: $\quad$ traditional market, web based

\section{PENDAHULUAN}

Pasar tradisional memegang peranan yang sangat penting dalam kegiatan ekonomi masyarakat terutama bagi penjual produk-produk kebutuhan pokok yang dihasilkan oleh para pelaku ekonomi bersekala menengah kecil serta mikro. Kebutuhan informasi pasar tradisional bagi masyarakat di Kabupaten Jembrana merupakan bagian yang sangat penting di era teknologi informasi saat ini. Hal tersebut didasarkan pada minimnya informasi tentang pasar tradisional seperti informasi lokasi pasar, komoditas pasar dan informasi-informasi lainnya yang bermanfaat bagi masyarakat.

Kabupaten Jembrana memiliki beberapa pasar tradisional yang tersebar di semua kecamatan. Keberadaan pasar tradisional di kabupaten Jembrana memegang peran yang sangat besar bagi pertumbuhan ekonomi di daerah ini. Namun seiring perkembangan jaman, keberadaan pasar tradisional mulai tergantikan oleh pasar modern dan toko modern. Diperlukan sebuah inovasi teknologi dalam pengelolaan pasar tradisional untuk dapat bersaing pada era teknologi informasi saat ini.

Perkembangan teknologi informasi seperti yang kita ketahui saat ini sangat berkembang pesat. Akan sangat bermanfaat apabila pemerintah kabupaten Jembrana bisa memanfaatkan teknologi infromasi yang ada saat ini untuk menunjang kebutuhan data dan infromasi pasar tradisional di wilayah kabupaten Jembrana. Apabila teknologi informasi bisa dimanfaatkan dengan 
baik dalam pengolahan data dan informasi pasar tradisional di kabupaten Jembrana, data yang informasi yang diperoleh akan lebih valid, menghemat biaya dan tempat serta tidak terlalu banyak menyita waktu.

Berdasarkan permasalahan di atas penelitian ini memberikan solusi untuk pengolahan data dan infromasi pasar tradisional di kabupaten Jembrana yaitu dengan manajemen pasar tradisional berbasis web. Sistem ini dapat menampilkan informasi lengkap mengenai pasar tradisional yang ada di seluruh kabupaten Jembrana. Selain itu, sistem juga ini menyajikan update informasi tentang harga produk pada setiap pasar. Dengan adanya manajemen pasar tradisional berbasis web ini diharapkan dapat menarik minat masyarakat untuk mengunjungi pasar tradisional karena informasi sudah dapat diakses secara online.

\section{TINJAUAN PUSTAKA \\ Pasar Tradisional}

Pasar merupakan sebuah tempat untuk berkumpulnya orangorang dalam hubungan sosial melalui bentuk penjualan dan pembelian barang, jasa dan tenaga kerja dengan menggunakan uang sebagai alat tukarnya, untuk memenuhi kebutuhan masyarakat penggunanya dengan jaminan masyarakat akan mendapatkan keamanan, kenyamanan, dan kepuasan [1].

Pasar Tradisional adalah Pasar yang dibangun dan dikelola oleh Pemerintah, Pemerintah Daerah, Badan Usaha Milik Negara dan Badan Usaha Milik Daerah termasuk kerjasama dengan swasta dengan tempat usaha berupa toko, kios, los dan tenda yang dimiliki atau dikelola oleh pedagang kecil, menengah, swadaya masyarakat atau koperasi dengan usaha, modal kecil dan dengan proses jual beli barangdagangan melalui tawar menawar [2].

\section{Web}

Sebuah situs web (sering pula disingkat menjadi situs saja, website atau site) adalah sebutan bagi sekelompok halaman web (web page), yang umumnya merupakan bagian dari suatu nama domain ( domain name ) atau subdomain di World Wide Web (WWW) di Internet. Sebuah web page adalah dokumen yang ditulis dalam format HTML (Hyper Text Markup Language), yang hampir selalu bisa diakses melalui HTTP, yaitu protokol yang menyampaikan informasi dari server website untuk ditampilkan kepada para pemakai melalui web browser baik yang bersifat statis maupun dinamis yang membentuk satu rangkaian bangunan yang saling terkait dimana masing-masing dihubungkan dengan jaringanjaringan halaman (hyperlink) [3].

Website ini dibuka melalui sebuah program penjelajah (Browser) yang berada di sebuah komputer. Program penjelajah yang bisa digunakan dalam komputer diantaranya: IE (Internet Explorer ), Mozilla, Firefox, Netscape, Opera dan yang terbaru adalah Google Chrome [4].

\section{METODE PENELITIAN}

Jenis Metode Penelitian yang dipiih adalah metode deskriptif. Metode Deskriptif adalah suatu metode yang berfungsi untuk mendeskripsikan atau memberi gambaran terhadap objek yag diteliti melalui data atau sampel yang telah terkumpul sebagaimana adanya (fakta) 
Journal of Applied Management and Accounting Science ( J A M A S )

(I Gusti Putu Suwiarta Aquariawan 149 - 157)

Vol 1, No 2, Juli 2020

[5]. Berikut ini adalah tahapan tradisional berbasis web sebagai
penelitian dari manajemen pasar

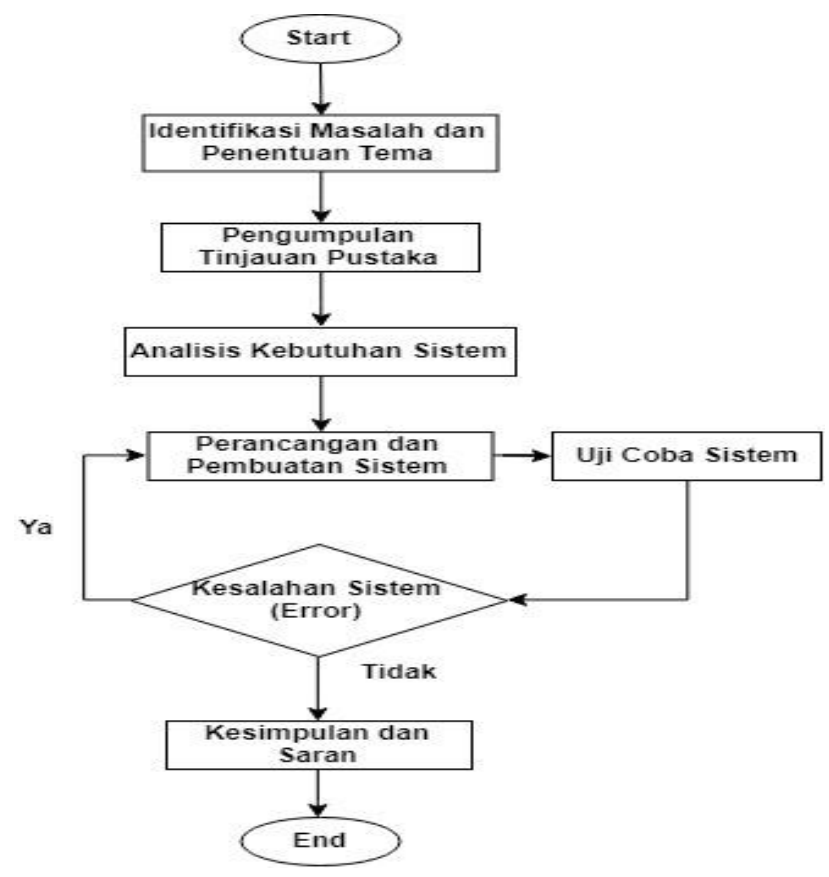

Gambar 1 Tahapan Penelitian

Terdapat beberapa proses dalam penelitian tentang manajemen pasar tradisional berbasis web. Tahapan ini terdiri dari tahap identifikasi masalah, tahap pengumpulan tinjauan pustaka, analisis kebutuhan sistem, perancangan dan pembuatan sistem, uji coba sistem, perbaikan sistem, dan penarikan kesimpulan.

\section{HASIL DAN PEMBAHASAN}

Pada hasil penelitian ini, penulis memberikan penjelaskan hasil dari penelitian yang dilakukan pada metodologi penelitian. Berikut ini penjelasan dari hasil yang dilakukan pada penelitian ini:

\section{Perancangan Sistem}

Perancangan sistem dirancang untuk mengetahui alur serta proses data yang terjadi di dalam sistem yang akan dibuat. Beikut ini adalah perancangan sistem dari manajemen pasar tradisional berbasis web : 


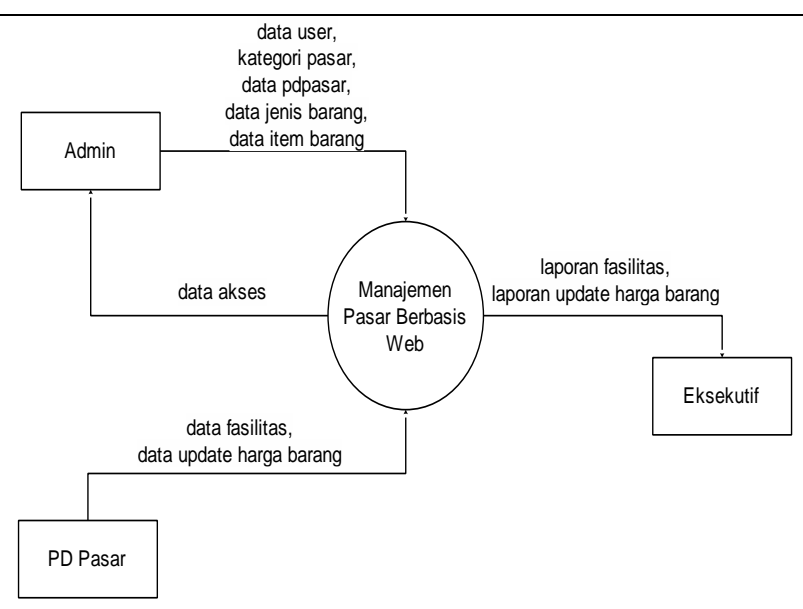

\section{Gambar 2 Perancangan Sistem}

Pada perancangan sistem di atas terlihat beberapa entitas yang terlibat dalam sistem, yaitu admin, pdpasar, dan eksekutif. Admin memasukkan data user, kategori pasar, pdpasar, jenis barang, dan item barang ke dalam sistem. PD Pasar memasukkan data fasilitas dan update harga barang, sedangkan eksekutif menerima laporan fasilitas dan laporan update harga barang.

Implementasi

a. Halaman Login

Halaman ini terdapat sebuah form yang harus diisi oleh admin. Admin mengisikan Username dan Password sebelum mengakses ke dalam sistem, Halaman Login ditujukan pada gambar berikut.

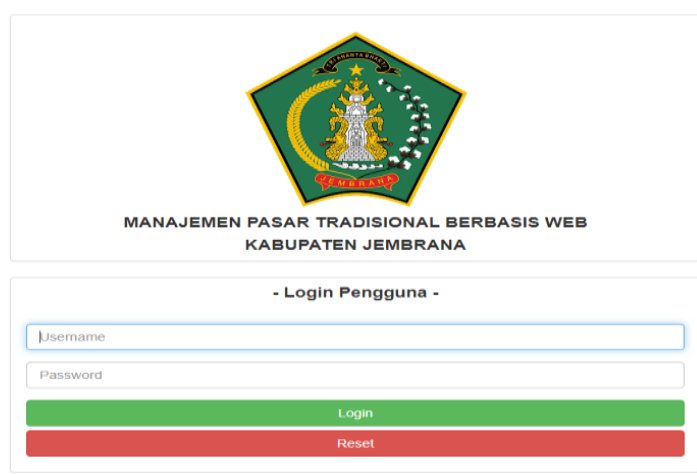

Gambar 3 Halaman Login

b. Halaman Admin

Pada halaman ini terdapat beberapa menu diantaranya, menu master data user, kategori pasar, lokasi, pd pasar, jenis, item barang, serta laporan-laporan. 


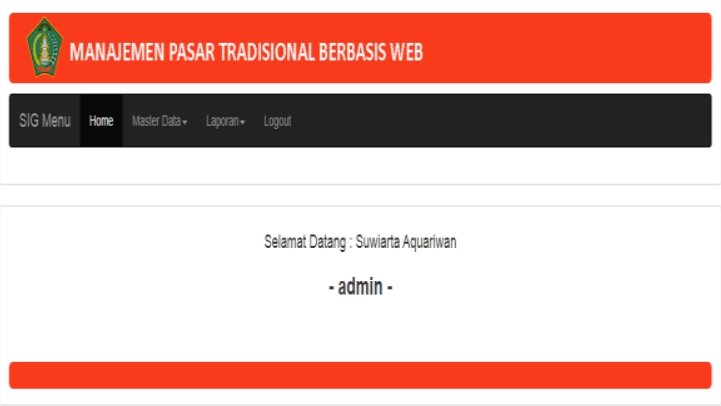

\section{Gambar 4 Halaman Admin}

c. Halaman Kategori Pasar

Pada halaman berisi inputan data kategori pasar, yaitu menampilkan data view kategori pasar, tambah data pasar, edit kategori, dan hapus kategori pasar.

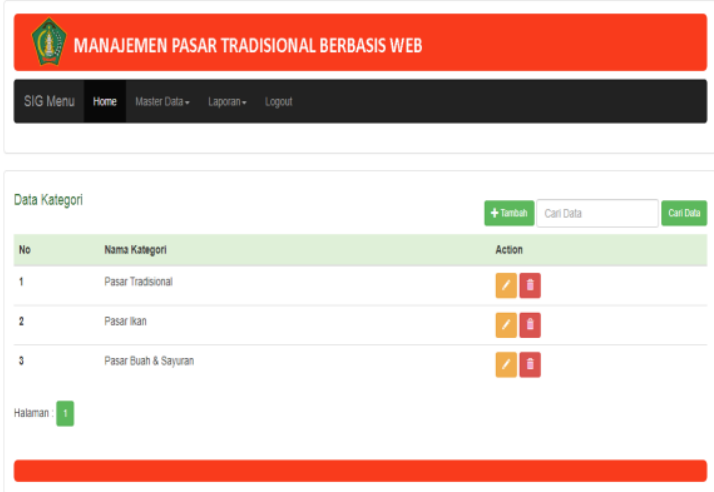

Gambar 5 Halaman Kategori Pasar

c. Halaman Lokasi Pasar

Pada halaman berisi inputan data

lokasi pasar, yaitu menampilkan data view lokasi pasar, tambah data, edit, dan hapus lokasi pasar.

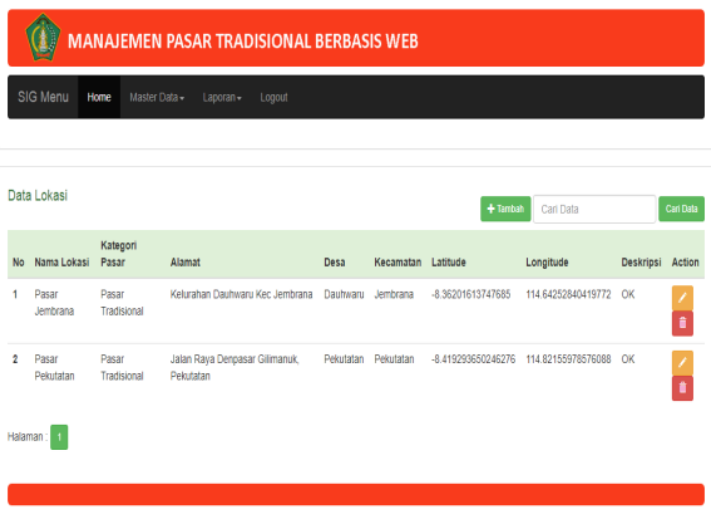

\section{Gambar 6 Halaman Lokasi Pasar}

d. Halaman Pengelola PD Pasar

Pada halaman berisi inputan data pengelola pd pasar, yaitu menampilkan data view pengelola pasar, tambah data, edit, dan hapus pengelola pasar. 

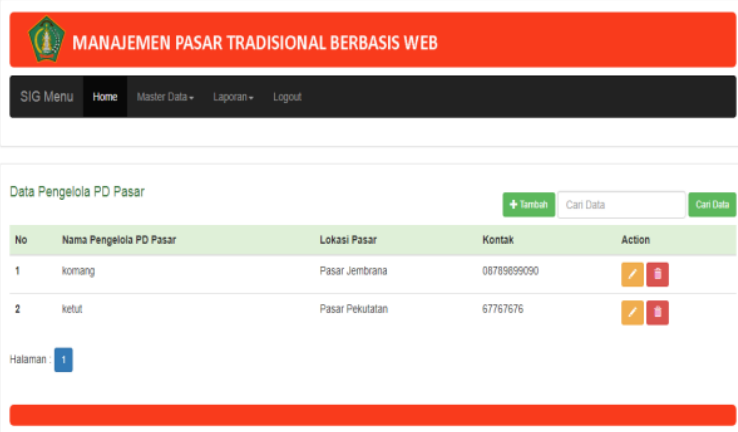

Gambar 7 Halaman Pengelola PD Pasar

e. Halaman Jenis Barang

Pada halaman berisi inputan data jenis barang, yaitu menampilkan data view jenis barang, tambah data, edit, dan hapus jenis barang.

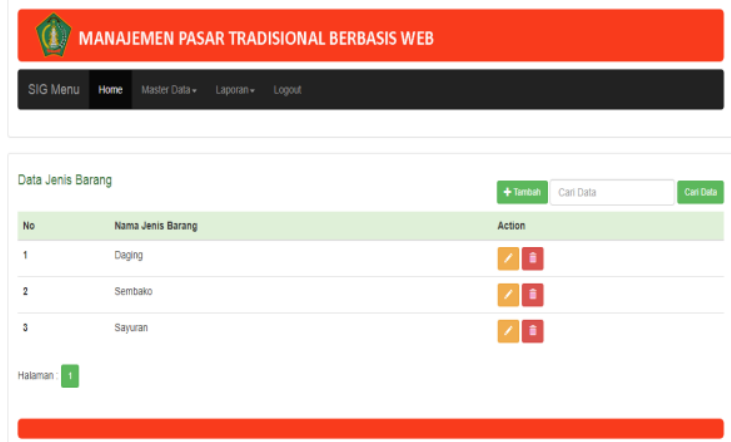

\section{Gambar 8 Halaman Jenis Barang}

f. Halaman Item Barang

Pada halaman berisi inputan data item barang, yaitu menampilkan data view item barang, tambah data, edit, dan hapus item barang.

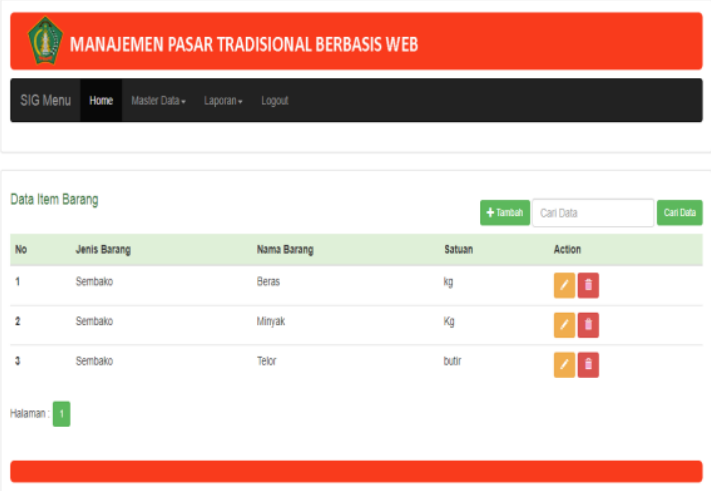

Gambar 9 Halaman Item Barang

f. Halaman Laporan Fasilitas

Pada halaman ini berisi laporan fasilitas pasar yang berisi informasi tentang nama pasar, alamat, luas pasar, luas parkir, fasilitas toilet, dan fasilitas parkir. 
Journal of Applied Management and Accounting Science ( J A M A S )

(I Gusti Putu Suwiarta Aquariawan 149 - 157)

Vol 1, No 2, Juli 2020
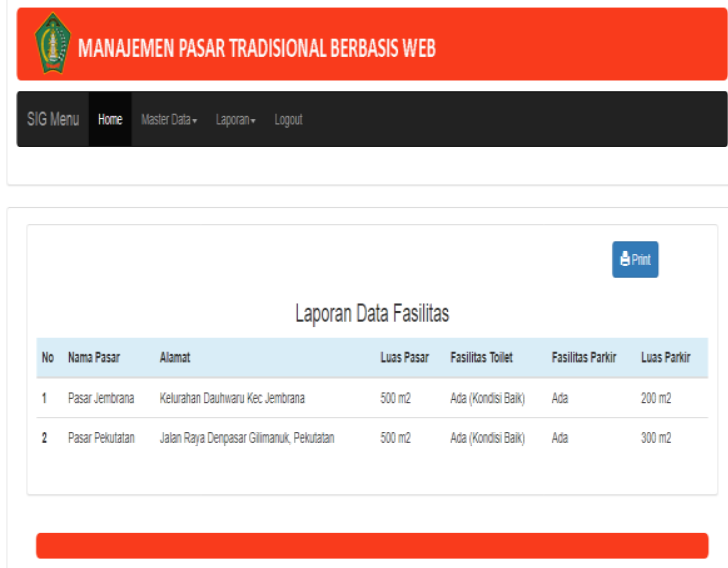

\section{Gambar 10 Halaman Laporan Fasilitas}

f. Halaman Laporan Harga Barang

Pada halaman ini berisi laporan update harga barang di masing-masing pasar. Pada halaman ini juga dapat mencetak laporan dalam bentuk tabel maupun grafik.

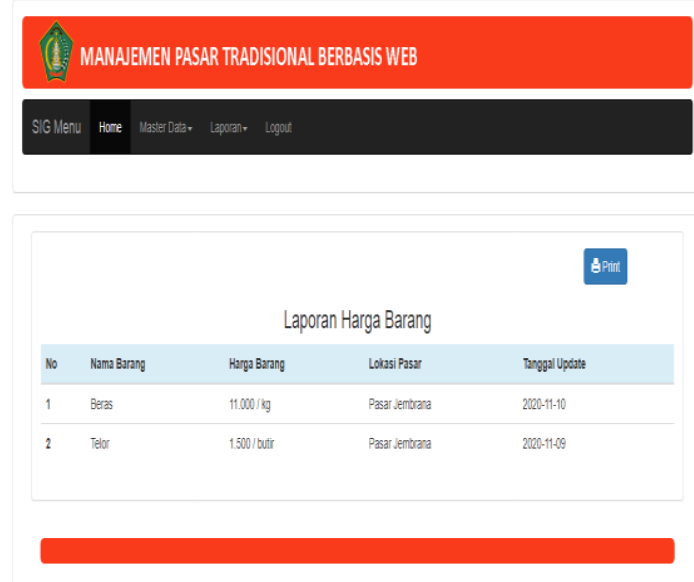

Gambar 11 Halaman Laporan Harga Barang

f. Halaman Website Pasar

Pada halaman website pasar ini berisi tentang informasi peta lokasi pasar, info terkini tentang PD pasar, serta info update harga barang dari masing-masing PD pasar yang ada di seluruh kabupaten Jembrana. 


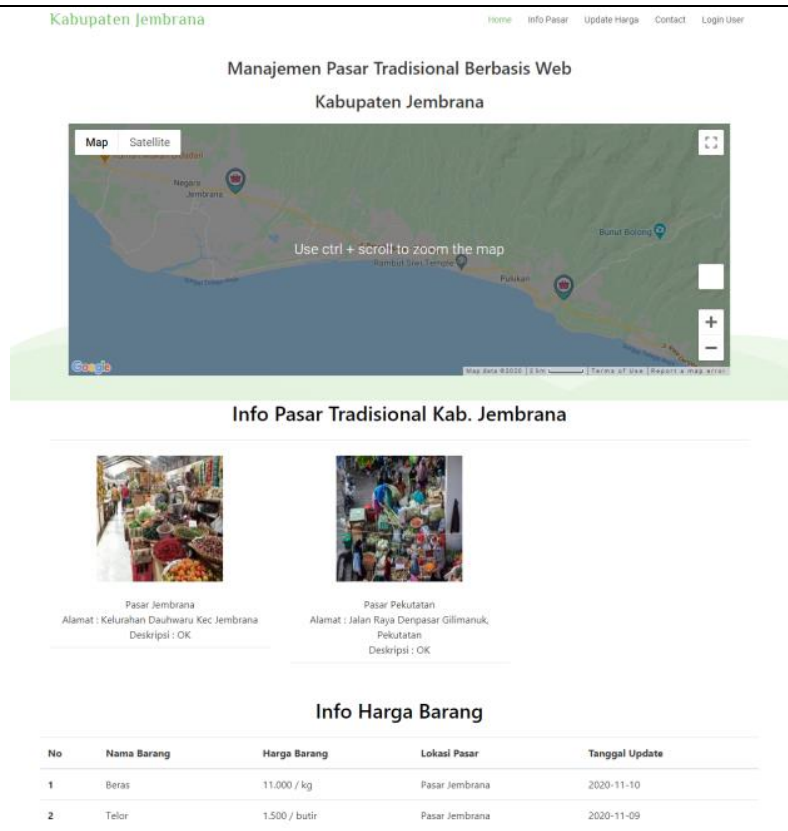

Gambar 12 Halaman Website Pasar

\section{SIMPULAN DAN SARAN}

Dengan adanya sistem ini diharapkan Pengelola Pasar yang ada di Kabupaten Jembrana dapat mengelola dan memanajemen pasar secara lebih profesional dengan bantuan teknologi informasi.

Selain itu sistem ini juga sebagai menyajikan informasi tentang pasar tradisional kepada masyarakat yang terdiri dari informasi peta lokasi pasar, info terkini tentang PD pasar, serta info update harga barang dari masing-masing PD pasar yang ada di seluruh kabupaten Jembrana.

\section{DAFTAR PUSTAKA}

D. Syarifuddin et al., 2018. "Pasar Tradisional Dalam Perspektif Nilai Daya Tarik Wisata," $J$. Manaj. Resort dan Leis., vol. 15, no. 1, pp. 19-32.

Peraturan Presiden Republik Indonesia, Nomor 112 Tahun 2007 Tentang Penataan dan Pembinaan Pasar Tradisional, Pusat Perbelanjaan dan Toko
Modern.

Ali Zaki, 2009. Kiat Jitu Membuat Website Tanpa Modal. Jakarta: Elexmedia Komputindo.

R. Harminingtyas, 2014. "ANALISIS

LAYANAN WEBSITE

SEBAGAI MEDIA

PROMOSI, MEDIA

TRANSAKSI DAN MEDIA

INFORMASI DAN

PENGARUHNYA

TERHADAP BRAND

IMAGE PERUSAHAAN

PADA HOTEL CIPUTRA DI

KOTA SEMARANG," J. STIE

SEMARANG, vol. 6, no. 3.

Sugiyono, 2009. Metode Penelitian Kuantitatif, Kualitatif dan $R \& D$. Bandung: Alfabet.

Elisabet Yunaeti Anggreni dan Rita Irviani, 2017. Pengantar Sistem Informasi, Penerbit ANDI OFFSET, Yogyakarta 
Journal of Applied Management and Accounting Science ( J A M A S )

(I Gusti Putu Suwiarta Aquariawan 149 - 157)

Vol 1, No 2, Juli 2020

Ahmat Adil, 2017. Sistem Informasi

Geografis, Andi Yogyakarta.

Supono dan Virdiandry Putratama,

2018. Pemrograman Web

dengan Menggunakan PHP

dan Framework Codeigniter.

Albert Kurniawan, 2010. Belajar Mudah spss untuk pemula, Yogyakarta, Mediakom.

Sugiyono, 2009. Metode Penelitian

Kuantitatif, Kualitatif dan

R\&D, Bandung, Alfabeta. 